\title{
PEMBERDAYAAN UMKM DI KAWASAN SAÈ SALÈRA DAN SA ̇̇ RASSAH PAMEKASAN MELALUI KUR DI BRI CABANG PAMEKASAN
}

\author{
Rudy Haryanto
}

\begin{abstract}
Abstrak
Modal usaha bagi UMKM merupakan permasalahan yang cukup pelik. Untuk mengatasi hal tersebut pendekatan yang perlu dilakukan adalah penyediaan jasa keuangan mikro (micro finance). Untuk itu Bank BRI memiliki komitmen membantu mengembangkan UMKM melalui penyaluran kredit bantuan modal usaha berupa KUR. Pendekatan dalam penelitian ini secara kualitatif yang diarahkan pada penelitian lapangan dengan menggunakan pendekatan yuridis normatif. Hasil penelitian menunjukan bahwa Pertama: UMKM yang berada di kawasan Saè Salèra dan Saè Rassah yang berjumlah 94 pengusaha semuanya telah mendapatkan KUR Mikro dari Bank BRI, hal ini menunjukan antusiasme pelaku UMKM dan kepedulian Bank BRI Cabang pamekasan; Kedua: Bank BRI sebagai penyalur/kreditur KUR Mikro langsung kepada UMKM melakukan evaluasi/monitoring kepada UMKM yang telah mendapatkan KUR Mikro yang dilakukan setiap tiga bulan selama masa kredit dengan focus terhadat asset, omset, modal dan persediaan barang yang dimiliki UMKM, hal ini sesuai dengan Peraturan Menteri keuangan No 189/PMK.05/2010; Ketiga: Pada awalnya Bank BRI Pamekasan mengalami kendala tetapi saat ini tidak ada kendala yang cukup berarti dalam penyaluran KUR, karena informasi yang ditentang KUR sudah cukup memadadi bagi pelaku UMKM di kawasan Saè Salèra dan Saè Rassah; Keempat: Harapan Bank BRI cabang Pamekasan terhadap UMKM dan UMKM di kawasan Saè Salèra dan Saè Rassah khususnya adalah merealisasikan salah satu misi Bank BRI yaitu BRI melakukan kegiatan perbankan yang terbaik dengan memprioritaskan pelayanan kepada Usaha Mikro.
\end{abstract}

\section{Kata Kunci : KUR Mikro, UMKM, Saè Salèra, Saè Rassah}

Modal usaha bagi kelompok usaha kecil merupakan permasalahan yang cukup pelik. Tidak hanya menghambat kelangsungan bisnis tetapi bisa mejadi penyebab gagalnya usaha yang tengah dirintis. UMKM (Usaha Mikro Kecil dan Menengah) yang mayoritas Usaha Mikro berbentuk usaha rumah tangga, pedagang kaki lima, dan berbagai jenis usaha mikro lain yang bersifat informal dan masih sangat kekurangan modal usahanya. Padahal pada UMKM sektor inilah yang paling banyak menyerap tenaga kerja (pro job) dan mampu menopang peningkatan taraf hidup masyarakat (pro poor).

jsh Jurnal Sosial Humaniora, Vol 5 No.1, Juni 2012 
Untuk mengatasi hambatan permodalan UMKM, pendekatan yang perlu dilakukan adalah penyediaan jasa keuangan mikro (microfinance). Selama ini Lembaga Keuangan Mikro (LKM) merupakan lembaga yang mampu memenuhi kebutuhan modal UMKM karena mampu menyesuaikan dengan karakteristik UMKM yang cenderung dianggap tidak bankable oleh sektor perbankan komersial. LKM mampu memberikan pelayanan kredit dalam skala besar tanpa jaminan, tanpa aturan yang ketat, dan dengan cara itu pula mampu untuk menutup seluruh biaya yang mereka keluarkan. Selain itu LKM dapat juga menjadi perpanjangan tangan dari lembaga keuangan.1

Dalam rangka tersebut Senin 5 November 2007 Presiden Susilo Bambang Yudhoyono meresmikan program penjaminan kredit pembiayaan kepada UMKM yang selanjutnya disebut Kredit Usaha Rakyat (KUR) mendapat respon positif dari masyarakat. Program yang sangat populis ini bertujuan mengatasi masalah kesulitan kalangan pelaku UMKM. Program KUR ini didukung oleh enam Bank pelaksana atau penyalur yang salah satunya adalah Bank Rakyat Indonesia (BRI), serta di dukung oleh perusahaan penjaminan yaitu PT. Asuransi Kredit Indonesia (Askrindo) dan Perusahaan Umum Jaminan Kredit Indonesia (Perum Jamkrindo). Dimana Bank BRI ditunjuk oleh pemerintah sebagai sebagi lembaga perbankan yang memberikan KUR Mikro langsung kepada UMKM.

Bank BRI yang merupakan Bank milik Pemerintah memiliki komitmen untuk membantu mengembangkan UMKM serta meningkatkan kesejahteraan masyarakat. Salah satu bentuk komitment itu adalah dengan menjadi pilar penyaluran kredit untuk Modal usaha bagi UMKM dan Koperasi yang berupa KUR tersebut. Bank BRI melalui KUR ini bermaksud memberikan kemudahan akses yang lebih besar bagi para pelaku UMKM berdasarkan kelayakan usaha yang akan dilaksanakannya (feasible) dan bukan berdasarkan kelayakan pengusaha UMKM sebagai debitur (bankable) untuk mendapatkan modal usaha. Diharapkan melalui KUR ini yang merupakan pinjaman modal usaha menjadikan alternatif yang cocok bagi pemberdayaan dan pengembangan pelaku UMKM.

1Dr. B.S. Kusmulyono., Menciptakan Rakyat Berusaha. Bogor: IPB Press, 2009. hlm 183.

$$
\text { jsh Jurnal Sosial Humaniora, Vol } 5 \text { No.1, Juni }
$$


Sejak diluncurkan oleh Presiden Republik Indonesia tanggal 5 November 2007 penyaluran KUR mengalami kenaikan sekitar 9,5 (sembilan koma lima) kali lipat selama tahun 2008 dari Rp. 1.400.000.000.000,- (satu triliun empat ratus milyar rupiah) pada Januari 2008 menjadi Rp. 12.900.000.000.000,- (dua belas triliun sembilan ratus milyar rupiah) pada Januari 2009, yang kemudian melambat dan mencapai Rp. 17.200.000.000.000,- (tujuh belas triliun dua ratus milyar rupiah) pada akhir Desember 2009. Sebaran realisasi KUR menurut sektor menunjukkan peran sektor perdagangan mencapai $70 \%$ (tujuh puluh persen), sementara sektor pertanian 15\% (lima belas persen), sektor jasa lain-lain 7\% (tujuh persen), dan sektor lainnya 8\% (delapan persen). Sebaran realisasi KUR menurut wilayah, menunjukkan Jawa Timur, Jawa Tengah, dan Jawa Barat merupakan penerima terbesar KUR secara nasional.2

Penilaian tersebut apabila ditinjau dari aspek cakupannya memang menunjukkan bahwa program KUR ini cukup efektif dalam memperkuat permodalan UMKM. Namun perlu juga diperhatikan juga tolok ukur lainnya yang belum di kaji seperti ; kemampuan pengembalian dan pemanfaatan pinjaman oleh peminjam, dalam hal ini UMKM. Karena pada dasarnya tujuan diluncurkannya KUR adalah untuk mempercepat pengembangan sektor riil dan pemberdayaan UMKM, untuk meningkatkan akses pembiayaan kepada UMKM dan Koperasi, dan untuk perluasan kesempatan kerja dan penanggulangan kemiskinan.

Dengan melihat tiga tujuan tersebut diatas masih perlu dievaluasi apakah praktik di lapangan telah sejalan ataukah justru masih terdapat kendala yang cukup berarti, baik yang dihadapi oleh calon debitur dalam hal ini UMKM, perbankan sebagai kreditur (dalam hal ini Bank BRI), maupun pihak penjamin (PT. Askrindo dan Perum. Jamkrindo). Dimana penyaluran pola penjaminan difokuskan pada lima sektor usaha salah satunya sektor perindustrian dan perdagangan yang merupakan basis UMKM.

Dan apabila tidak ada upaya khusus dari pemerintah dan semua pihak yang terkait dikhawatirkan perbankan masih akan menghadapi kesulitan untuk dapat 
memberikan kredit kepada UMKM karena pada umumnya walaupun UMKM telah feasible namun belum bankable. Untuk itu pemerintah selaku penanggung jawab KUR melaui perbankan dituntut menerapkan manajemen risiko sesuai dengan kondisi UMKM khususnya dan kondisi makro ekonomi Indonesia umumnya. Sehingga program tersebut akan menarik minat para UMKM sehingga dampaknya bisa dirasakan secara signifikan oleh para pelaku UMKM di tingkat akar rumput (graas root).

Jenis UMKM perkotaan di Pamekasan akhir-akhir ini mengalami peningkatan dibanding tahun sebelumnya. Peningkatan tersebut dibuktikan dengan meningkatnya jumlah pedagang yang bergerak di bidang UMKM semisal Pedagang Kaki Lima (PKL). Hal ini dibuktikan adanya 37 unit* usaha baru di kota Pamekasan memasuki pertengahan 2011.3

Dalam rangka pemberdayaan masyarakat melalui pengembangan UMKM Pemerintah Kabupaten (Pemkab) Pamekasan menetapkan tiga lokasi untuk tempat usaha para pedagang kaki lima yang tergolong dalam UMKM yang berfokus pada usaha makanan dan minuman yang dikemas sebagai wisata kuliner. Ketiga lokasi yang di kembangkan tersebut dan merupakan binaan dari Dinas Koperasi dan UKM Pemkab Pamekasan masing-masing di Jalan Niaga yang diberi nama Saè Salèra, Jalan Dirgahayu Saè Rassah dan Jalan Trunojoyo dikawasan eks Stasiun Kereta Api yang belum diberi nama.

Berdasarkan fenomena di atas, maka ada beberapa permasalahan yang perlu diteliti tentang seberapa jauh pemberdayaan UMKM di kawasan Saè Salèra dan Saè Rassah Pamekasan dengan menggunakan modal dari KUR di BRI Cabang Pamakasan. Adapun rumusan masalah dalam penelitian ini adalah sebagai berikut: 1) Apakah semua UMKM di kawasan Saè Salèra dan Saè Rassah mendapatkan KUR dari Bank BRI?; 2) Apakah dilakukan evaluasi yang berkelanjutan terhadap kemajuan usaha kepada UMKM di kawasan Saè Salèra dan Saè Rassah yang mendapat KUR dari Bank BRI?; 3) Apakah Kendala yang dihadapi Bank BRI dalam penyaluran KUR?; 4) Apakah harapan Bank BRI sebagai penyalur KUR kepada UMKM di kawasan Saè Salèra dan Saè Rassah?

3Dinas Perindustrian dan Perdagangan (Disperindag) Kabupaten Pamekasan Juli 2011

$$
\text { jsh Jurnal Sosial Humaniora, Vol } 5 \text { No.1, Juni }
$$


Dari masalah yang akan dijadikan fokus penelitian di atas maka secara diskriptif penelitian ini bertujuan : 1) Mengetahui UMKM di kawasan Saè Salèra dan Saè Rassah yang mendapatkan KUR dari Bank BRI; 2) Mengetahui apakah dilakukan evaluasi yang berkelanjutan terhadap kemajuan usaha kepada UMKM di kawasan Saè Salèra dan Saè Rassah yang mendapat KUR dari Bank BRI; 3) Mengetahui kendala yang dihadapi Bank BRI dalam penyaluran KUR; dan 4) Mengetahui harapan Bank BRI sebagai penyalur KUR kepada UMKM di kawasan Saè Salèra dan Saè Rassah.

Sehingga dari hasil penelitian ini dapat dijadikan indicator keberhasilan penyaluran KUR di BRI Cabang Pamekasan, karena dengan pemberian kredit bantuan modal usaha berupa KUR yang dilakukan sesuai dengan ketentuan yang berlaku akan meningkatkan akses pembiayaan dan mengembangkan UMKM di Pamekasan. Karena pada kenyataannya berkembangnya UMKM ini mampu menyerap tenaga kerja yang sangat besar dan memberdayakan masyarakat. Bantuan kredit modal usaha melalui KUR dari Bank BRI ini di harapkan akan mengurangi angka pengangguran dan angka kemiskinan dan akan mempermudah penyaluran modal usaha bagi rakyat untuk mengembangkan usahanya, dan akhirnya mampu mendorong tumbuhnya ekonomi rakyat secara signifikan khususnya pelaku UMKM di kawasan Saè Salèra dan Saè Rassah Pamekasan.

\section{Metode Penelitian}

Pendekatan penelitian yang akan dipergunakan dalam penelitian ini adalah metode penelitian kualitatif, dengan model penelitian naturalistik yang karasteristik datanya dinyatakan dengan sewajarnya atau sebagaimana yang terjadi (natural setting), dengan tidak dirubah dalam bentuk simbol-simbol dan bilangan.4 Sebagaimana pengertian di atas, menurut Arif Furchan menyatakan bahwa metode kualitatif adalah prosedur penelitian yang menghasilkan data diskriptif, yaitu ucapan atau tulisan dan perilaku yang dapat diamati dari orang (subyek) itu sendiri.5

4h. Hadari Nawawi., Penelitian Terapan. Yogyakarta: UGM University Press,1994. hlm 174.

5Arif Furchan., Metode Penelitian Kualitatif. Surabaya: Usaha Nasioanal, 1992. hlm 21. 
Dengan kata lain bahwa penelitian kualitatif naturalistik adalah penelitian yang memfokuskan kajiannya terhadap fenomena secara holistik dan tidak mereduksi fenomena tersebut ke dalam variabel-variabel yang dicari hubungannya secara parsial akan tetapi fenomena tersebut dilihat sebagai bagian dari keseluruhan. Selain hal tersebut juga menggunakan pendekatan yuridis normatif, mengingat bahwa yang akan diungkap adalah masalah aturan dan norma, yakni pelaksanaan KUR Mikro di Bank BRI Kantor Cabang Pamekasan dengan menggunakan peraturan perundang-undangan, yaitu Peraturan Menteri Keuangan Nomor: 189/PMK.05/2010 Tentang Perubahan Ketiga Atas Peraturan Menteri Keuangan Nomor 135/PMK.05/2008 Tentang Fasilitas Penjaminan Kredit Usaha Rakyat. Keputusan Deputi Bidang Koordinasi Ekonomi Makro Dan Keuangan Kementrian Koordinator Bidang Perekonomian Selaku Ketua Pelaksana Komite Kebijakan Penjaminan Kredit/Pembiayaan Kepada Usaha Mikro, Kecil, Menengah dan Koperasi Nomor: $\quad$ Kep.01/ D.I.M.EKON/ 01/2010 Tentang Standarisasi Operasional Dan Prosedur Pelaksana Kredit Usaha Rakyat. Undang-Undang Republik Indonesia No 20 tahun 2008 tentang “Usaha Mikro Kecil dan Menengah".

Sedangkan jenis penelitiannya adalah penelitian lapangan dengan upaya memehami respon yang diteliti langsung yaitu pimpinan Bank BRI Cabang Pamekasan dan Kaunit BRI yang direkomendasikan sebagai pemengku kebijakan penyaluran kredit KUR Mikro kepada UMKM di kawasan Saè Salèra dan Saè Rassah pada khususnya.

Dalam penelitian ini, peneliti merupakan instrumen kunci, sehingga peneliti mutlak dituntut kehadirannya di lokasi penelitian dalam rangka mengumpulkan informasi yang valid terkait respon pimpinan Bank BRI Cabang Pamekasan dan Kaunit BRI yang direkomendasikannya sebagai pemengku kebijakan penyaluran kredit KUR Mikro kepada UMKM di kawasan Saè Salèra dan Saè Rassah, yaitu di kantor BRI Cabang Pamekasan dan kantor BRI Unit Trunojoyo.

Lokasi penelitian ini di wilayah kabupaten Pamekasan, dengan tempat wawancara di Bank BRI Cabang Pamekasan Jalan Jokotole 24 Pamekasan sebagai 
induk dari Unit-Unit Bank BRI di wilayah Pamekasan dan kantor BRI Unit Trunojoyo yang direkomendasikan pimpinan Bank BRI Cabang Pamekasan.

Jenis data dalam penelitian ini adalah data kualitatif, tentang pemberdayaan UMKM di kawasan Saè Salèra dan Saè Rassah melalui KUR di BRI Cabang Pamekasan sesuai hasil wawancara. Data tersebut diperoleh melalui wawancara dan pengamatan yang merupakan suatu usaha gabungan dari melihat, mendengar dan bertanya dengan pimpinan Bank BRI Cabang Pamekasan. Sumber data ini dikategorikan sumber data manusia, sekaligus sumber data primer.6

Untuk memperoleh data dari sumber data primer tersebut diatas, peneliti menggunakan metode wawancara bebas terpimpin. Sumber data wawancara dilakukan dengan pimpinan (stake holder) Bank BRI Cabang Pamekasan dan Kaunit BRI yang direkomendasikannya sebagai pemengku kebijakan penyaluran kredit KUR Mikro kepada UMKM di kawasan Saè Salèra dan Saè Rassah pada khususnya.

Sedangkan data sekunder berupa Undang-Undang, Peraturan Menteri, Surat Edaran BRI, Formulir-formulir yang ada di Bank BRI yang berhubungan dengan aturan dan kebijakan tentang KUR Mikro dan UMKM. Yang data tersebut didapatkan dari refrensi di Bank BRI, Dinas Koperasi dan UKM Kabupaten Pamekasan, Dinas Perindustrian dan Perdagangan Kabupaten dan Asosiasi Pedagang Kaki Lima Indonesia (APKLI) cabang Pamekasan.

Metode pengumpulan data adalah perangkat untuk mengenali data primer dari responden sebagi sumber data terpenting dalam sebuah penelitian. Metode pengumpulan data ilmu sosial umumnya berbentuk kuesioner dan pedoman pertenyaan/wawancara (interview guide). Semua jenis metode pengumpulan data ini berisi rangkaian pertanyaan mengenai suatu hal atau permasalahan yang menjadi tema pokok peneltian.7

Metode yang digunakan dalam pengumpulan data adalah dengan wawancara (interview guide). Sedangkan jenis wawancara yang digunakan hlm 162

6Winarno Surakmad., Pengantar Penelitian Ilmiah Dasar Metoda Tehnik. Jakarta: Tarsito, 1980.

7Bagong Suyanto dan Sutinah. ad., Metode Peneltian Sosial: Berbagai Alternatif Pendekatan. Edisi Pertama, Cetakan ke-2. Jakarta: Kencana, 2006. hlm 59 
adalah wawancara bebas terpimpin atau semi terbuka, yaitu jenis wawancara yang merupakan gabungan antara wawancara bebas dengan wawancara terpimpin. 8

Dengan jenis wawancara ini, peneliti telah mempersiapkan dengan matang pedoman-pedoman dalam melakukan wawancara dan juga memberikan kebebasan kepada informan untuk memberikan penjelasan panjang lebar namun tetap tidak keluar dari permasalahan yang diangkat. Hal ini bertujuan agar wawancara berlangsung terarah, luwes dan fleksibel berdasarkan pedoman yang telah dibuat sebelumnya.

Dalam analisis data, peneliti menggunakan cara yang dikemukakan oleh S. Nasution, yang terdiri dari tiga langkah;9 1) reduksi data, yaitu menyederhanakan data ke dalam konsep, klasifikasi dan ciri-ciri yang melekat pada dirinya, 2) sajian data, yaitu proses uraian data dalam bentuk penjelasan verbal dan 3) pengambilan kesimpulan, yaitu penyimpulan temuan lapangan yang selanjutnya dikonfirmasikan dengan teori yang relevan yang nantinya akan menghasilkan temuan teroritis.

Untuk menjaga validitas data yang bisa dipertanggungjawabkan keabsahannya, maka peneliti berusaha mengeceknya secara teliti dengan teknik pengecekan keabsahan data sebagai berikut: 1)Ketekunan Pengamatan.Dengan ketekunan pengamatan dimaksudkan untuk menemukan ciri-ciri dan unsur-unsur dalam situasi yang sangat relevan. 2) Trianggulasi. Yang dimaksud trianggulasi adalah pemeriksaan keabsahan data yang dengan memanfaatkan sesuatu di luar data tersebut untuk pengecekan atau sebagai bahan pembanding terhadap data itu. 3) Perpanjangan Keikutsertaan. Perpanjangan keikutsertaan digunakan dengan pertimbangan: Pertama, agar dapat menguji ketidakbenaran informasi yang diperkenalkan. Kedua, Keharusan peneliti terjun ke dalam lokasi penelitian. Ketiga, membangaun kepercayaan para subjek terhadap peneliti dan kepercayaan diri peneliti sendiri.10

sibid, 65.

4 Nasution., Metode Penelitian Naturalistik-Kualititif. Bandung: Tarsito, 1992. hlm 128-130. 10Ibid., hlm. 193.

jsh Jurnal Sosial Humaniora, Vol 5 No.1, Juni 


\section{Hasil Penelitian dan Pembahasan}

Data hasil dari wawancara dengan responden diatas dianalisis berdasarkan rumusan masalah : Pertama : Apakah semua UMKM di kawasan Saè Salèra dan Saè Rassah Pamekasan mendapatkan atau pernah mendapatkan KUR dari Bank BRI?; Kedua : Apakah dilakukan evalusi terhadap kemajuan usahanya bagi UMKM di kawasan Saè Salèra dan Saè Rassah Pamekasan yang menerima KUR dari Bank BRI?; Ketiga: Apakah kendala yang dihadapi oleh Bank BRI dalam menyalurkan KUR khususnya terhadap UMKM di kawasan Saè Salèra dan Saè Rassah Pamekasan; Keempat: Apakah harapan Bank BRI sebagai Perbankan milik Pemerintah dan penyalur KUR terhadap pengembangan UMKM di khususnya di kawasan Saè Salèra dan Saè Rassah Pamekasan? Adapun analisis masalah diatas dijelaskan sebagai berikut:

Pertama, Apakah semua UMKM di kawasan Saè Salèra dan Saè Rassah Pamekasan mendapatkan atau pernah mendapatkan KUR dari Bank BRI? Berdasarkan wawancara peneliti dengan Bapak H. Ach. Suprapto, S.IP (Account Officer Komersial dan Program Bank BRI Cabang Pamekasan) dan Ibu Tuti Setiawati (Kaunit Bank BRI Trunojoyo Pamekasan) bahwa sejak diluncurkanya KUR pada tahun 2008 semua UMKM di kawasan Saè Salèra dan Saè Rassah telah mendapatkan KUR baik mikro maupun ritel, dan sampai sekarangpun masih banyak para pengusaha UMKM di kawasan Saè Salèra dan Saè Rassah yang masih menjadi debitur KUR di Bank BRI Pamekasan baik melalui Cabang maupun Unit. Hal ini dapat dilihat pada waktu itu adanya spanduk dari Bank BRI disetiap tenda usahanya.

Hal ini dapat dijastifikasikan bahwa para pengusaha UMKM di kawasan Saè Salèra dan Saè Rassah sudah mengetahui adanya program KUR dari pemerintah yang salah satunya melalui Bank BRI, para pengusaha UMKM di kawasan Saè Salèra dan Saè Rassah mengetahui prosedur mendapatkan bantuan modal uasaha dari KUR di Bank BRI Pamekasan, dan para pengusaha UMKM di kawasan Saè Salèra dan Saè Rassah juga mengetahui hak dan tanggung jawabnya sebagai debitur KUR di Bank BRI Pamekasan. 
Adapun prosedur pelayanan KUR Mikro di Bank BRI Pamekasan sebagai berikut: Suku bunga Kredit Usaha Rakyat (KUR) Mikro memiliki suku bunga flate atau sama rata dari awal hingga pelunasan kredit yaitu sebesar 1,025\%. Dan dananya seratus persen berasal dari dana bank. Dengan demikian bank harus menerapkan prudential principle dalam pelayanan KUR Mikro, salah satunya dengan prinsip pengenalan nasabah untuk memperkecil kemungkinan nasabah memberikan data palsu sehingga dapat memperkecil kemungkinan resiko kredit macet.

Ada beberapa persyaratan umum yang harus dipenuhi calon debitur untuk mengajukan KUR Mikro diantaranya :

1. Individu (perorangan) yang melakukan usaha produktif yang layak, yang belum pernah mendapat kredit/pembiayaan dari perbankan yang dibuktikan dengan hasil Bank Indonesia. Checking pada saat permohonan kredit diajukan dan atau belum pernah memperoleh fasilitas Kredit Program dari Pemerintah. Usaha produktif adalah usaha untuk menghasilkan barang atau jasa untuk memberikan nilai tambah dan meningkatkan pendapatan bagi debitur dari usaha yang dilakukan,

2. Dapat sedang menerima kredit konsumtif (Kredit Kepemilikan Rumah, Kredit Kendaraan Bermotor, kartu kredit, dan kredit konsumtif lainnya),

3. Usaha telah berdiri minimal 1 tahun,

4. Legalitas calon debitur terdiri dari identitas debitur berupa KTP (Kartu Tanda Penduduk) dan KK (Kartu Keluarga),

5. Perijinan usaha calon debitur berupa Surat Ijin Usaha dari Lurah atau Kepala desa tempat usaha berkedudukan.

Prosedur penerimaan nasabah dan pelayanan permintaan pinjaman KUR Mikro pada Bank BRI Pamekasan adalah sebagai berikut:

1. Nasabah datang dengan membawa persyaratan pengajuan pinjaman seperti yang telah disebutkan diatas,

2. Nasabah dilayani oleh Customer Service KUR dengan melakukan pemeriksaan persyaratan yang dibawa oleh calon debitur, bila dianggap memenuhi persyaratan, maka pengajuan calon debitur dapat dilayani, 
3. Calon debitur mengisi Form K5, yaitu formulir permohonan KUR,

4. Data debitur diproses melalui SID (Sistem Informasi Debitur) dengan Bank Indonesia (BI) Checking untuk memastikan calon debitur sedang tidak terikat dengan kredit konsumsi program pemerintah lainnya. Mengacu pada Peraturan Menteri Keuangan No. 135/PMK.05/2008 ketentuan nasabah yang mengajukan KUR Mikro merupakan usaha mikro yang produktif, dan belum pernah menikmati kredit/pembiayaan dari perbankan. Selama proses pemrosesan data calon debitur diperbolehkan pulang dan menunggu dihubungi kembali oleh pihak bank,

5. Persyaratan calon debitur dikumpulkan dalam satu map untuk diserahkan kepada Asisten Mantri untuk di lakukan analisis,

6. Mantri melakukan survey ketempat usaha calon debitur sebagai upaya penerapan prudential banking untuk memastikan data dan keterangan debitur adalah benar,

7. Bila hasil survey telah diputuskan, dan Asisten Mantri menyatakan data dan hasil survey benar, selanjutnya data nasabah diproses kedalam suatu program komputer yang disebut LAS (Loan Approval System),

8. Selanjutnya berkas diserahkan kepad Ka-Unit yang berwenang memutuskan pemberian kredit dengan melakukan approve atau persetujuan pada LAS untuk melakukan putusan kredit,

9. Setelah Ka-Unit memberi putusan kredit, Asisten Mantri kembali memverifikasi putusan Ka-Unit pada LAS.

10.Customer Service KUR menghungi calon debitur yang telah mendapat putusan pencairan kredit untuk melakukan realisasi kredit,

11.Calon debitur datang ke bank dan melakukan wawancara dengan Ka-Unit dan malakukan pembukaan rekening pinjaman, penandatanganan Surat Perjanjian Hutang (SPH) oleh kedua calon debitur (bila suami istri) di meja Customer Service KUR. Rekening pinjaman diberikan apabila debitur tidak memiliki buku tabungan sebagaimana halnya rekeniong simpanan,

12. Kwitansi pinjaman dan SPH ditandatangani oleh Customer Service KUR dan di fiat oleh Ka-Unit, 
13. Debitur melakukan pengambilan uang senilai pinjaman yang disetujui di Teller.

Setelah realisasi KUR, berkas debitur yang terdiri dari Identitas Debitur (KTP), pas photo, surat keterangan usaha, form K5 permohonan pinjaman KUR Mikro, kwitansi pinjaman, Surat Pengakuan Hutang (SPH) diarsipkan dengan Nomor Pangkal khusus sesuai urutan debitur ( untuk debitur baru), tidak perlu memakai Nomor Pangkal baru jika debitur lama.

KUR hanya dapat di peroleh sekali seumur hidup, apabila setelah melunasi pinjamannya yang pertama debitur ingin melakukan permohonan peminjaman lagi maka kredit yang diberikan adalah KSM (Kredit Skala Menengah), tidak perlu membuat Nomor Pangkal baru, untuk debitur yang memiliki reputasi baik pihak bank tidak perlu melakukan survey sehingga proses realisasinya dapat berlangsung lebih cepat. Pembukuan pada saat PH (Perjanjian Hutang) KUR dilakukan seperti pada Tabel 1 .

Tabel 1 Jurnal umum transaksi pembukuan PH

\begin{tabular}{|l|l|l|l|l|}
\hline No & Description & Ref & Debet & Credit \\
\hline & $\begin{array}{l}\text { Memo - PH Pinjaman Kontra - } \\
\text { memo PH Pinjaman Memo Adm. } \\
\text { Kewajiban debitur yang di-PH Kontra Adm. } \\
\text { Kewajiban debitur yang di-PH }\end{array}$ & & xxx & xxx \\
\hline
\end{tabular}

Pengajuan pinjaman dapat dilayani sampai tanggal 25 bulan yang bersangkutan dan penerimaan dibuka kembali pada tanggal 5 bulan berikutnya. Sedangkan prosedur pengelolaan KUR Mikro di Bank BRI Pamekasan sebagai berikut: KUR ini merupakan program pemerintah, namun dalam pelaksanaannya sumber dana KUR sepenuhnya berasal dari dana bank. Sesuai fungsinya sebagai lembaga intermediari sumber dana terbesar bank berasal dari masyarakat yang menyimpan dananya pada bank bersangkutan dan pendapatan terbesar bank adalah dari sektor kredit. Keuntungan jasa bank adalah selisih kewajiban bunga yang harus dibayar kepada nasabah penabung (kreditur) dengan bunga yang diterima bank dari aktifitas pemberian kredit. Dengan demikian, 
pengelolaan kredit adalah kunci utama bagi perbankan nasional untuk tetap bertahan dalam persaingan yang ketat, serta akan memberikan pendapatan atau keuntungan yang diharapkan.

Pengelolaan kredit diantaranya pengawasan kredit dan pengelolaan kredit bermasalah. Dalam hal pengawasan kredit, setelah realisasi KUR Mikro, maka Customer Service KUR dan Asisten Mantri wajib membuat register pengawasan, yang dapat dilakukan dengan dua cara yaitu pengawasan secara administratif oleh bank berdasarkan segala infornasi yang tersedia dan pengawasan secara langsung dengan melakukan kunjungan ke lokasi usaha debitur. Pengawasan secara langsung dapat dibuktikan dengan pengisian Formulir Kunjungan Nasabah. Pengawasan kredit berfungsi mengetahui secara dini penyimpangan yang terjadi atas pemberian kredit ke debitur.

Dalam hal pengelolaan kredit bermasalah, berdasarkan hasil pengawasan bank dapat segera mengambil langkah yang tepat dan cepat untuk mengantisipasi kemungkinan timbulnya resiko kredit macet. Kredit macet adalah kredit yang sejak jatuh tempo tidak dapat dilunasi oleh debitur sebagaimana mestinya sesuai dengan perjanjian.

Berdasarkan Surat Keputusan Direksi Bank Indonesia No. 30/267/KEP/DIR tanggal 27 Februari 1998, ditetapkan lima golongan kolektibilitas kredit, yaitu :

1. Lancar yaitu kredit dimana tidak terdapat tunggakan angsuran pokok, tunggakan bunga atau cerukan karena penarikan kredit,

2. Dalam Perhatian Khusus, dimana terdapat tunggakan angsuran pokok beserta bunga, dan belum melampaui 3 bulan, bagi kredit yang masa angsurannya bulanan. Dapat pula terjadi karena adanya indikasi masalah keuangan yang dihadapi debitur, jangka waktu kolektabilitas kredit yang tergolong perhatian khusus adalah 30 hari -90 hari,

3. Kurang Lancar dimana terdapat tunggakan melampaui 3 bulan (90 hari) dan belum melampaui 6 bulan (180 hari), bagi kredit yang masa angsurannya bulanan, 
4. Diragukan, dimana terjadi tunggakan melampaui 6 bulan (180 hari) dan belum melampaui 9 bulan (270 hari), bagi kredit yang masa angsurannya bulanan,

5. Macet, yaitu kolektabilitas kredit dimana terjadi tunggakan melampaui 9 bulan (270 hari) dan belum melampaui 12 bulan (360 hari).

Berdasarkan Inpres No. 6 tahun 2007, KUR Mikro mendapat penjaminan dari pemerintah melalui Perusahaan Penjamin PT. Asuransi Kredit Indonesia (Askirindo) sebesar 70\%. Bank BRI dapat mengajukan klaim KUR atas tunggakan yang terjadi, sedangkan sisanya yang sebesar 30\% ditanggung oleh bank pelaksana, dan bank tetap melakukan upaya penagihan kepada debitur.

Klaim adalah tuntutan pembayaran oleh penerima jaminan (Bank BRI) kepada penjamin (PT. Askrindo) yang diakibatkan terjamin (debitur) tidak dapat memenuhi kewajibannya sesuai dengan perjanjian. Berikut ini adalah prosedur pengelolaan kredit macet KUR Mikro pada Bank BRI :

1. Pada saat kredit masuk dalam golongan kolektabilitas diragukan paling lambat tanggal 20 setiap bulan setelah dinyatakan diragukan. Customer Service KUR membuat surat pengajuan klaim KUR.

2. Surat pengajuan klaim KUR tidak langsung di kirimkan oleh BRI Unit ke perusahaan Penjamin, melainkan harus melalui Kantor Cabang BRI. Adapun dokumen-dokumen yang dikirimkan antara lain:

a. Checlist lembar pengajuan klaim kepada perusahaan penjamin,

b. Permohonan pengajuan klaim atas nama debitur ditandatangani Pinca,

c. Surat pengajuan klaim penjaminan KUR ditandatangani oleh Ka-Unit,

d. Fotocopy identitas debitur (KTP),

e. Fotocopy Form K5,

f. Fotocopy Surat Keterangan Usaha,

g. Fotocopy Laporan Kunjungan Nasabah (Model 152),

h. Hasil BI Checking,

i. Surat keterangan dari pejabat berwenang yang menyatakan debitur melarikan diri, pindah tempat, atau meninggal,

j. Fotocopy Kartu Keluarga (KK),

k. Fotocopy sertifikat penjaminan atas nama debitur,

jsh Jurnal Sosial Humaniora, Vol 5 No.1, Jun 
1. Asli Rekening Koran dan Loan Pay Off,

m. Berita acara klaim.

3. Berkas debitur yang sudah masuk dalam golongan kolektibilitas Diragukan, kemudian dikelompokkan kedalam register DH (Daftar Hitam),

4. Setelah mendapat persetujuan pembayaran klaim kredit oleh PT. Askrindo, penjaminan KUR Mikro dibukukan sebagai pendapatan klaim, bukan sebagai angsuran pinjaman,

5. Walaupun telah masuk dalam register DH, Asistem Mantri senantiasa melakukan pendekatan dan kunjungan agar debitur dapat memenuhi kewajibannya kepada bank. Pembukuan pada saat penerimaan klaim dari perusahaan penjamin adalah :

a. Pada saat menerima ganti rugi dari perusahaan penjamin, pembukuan dilakukan seperti Tabel 2.

Tabel 2. Jurnal umum penerimaan ganti rugi

\begin{tabular}{|l|c|l|l|l|}
\hline No & Description & Ref & Debet & Credit \\
\hline & $\begin{array}{l}\text { Kas Kliring } \\
\text { Internal Account - Titipan hasil klaim }\end{array}$ & & $\mathrm{Xxx}$ & \\
\hline
\end{tabular}

b. Pengakuan pendapatan klaim, pembukuan dilakukan seperti Tabel 3.

Tabel 3. Jurnal umum pendapatan klaim

\begin{tabular}{|l|c|l|l|l|}
\hline No & Description & Ref & Debet & Credit \\
\hline & $\begin{array}{c}\text { Internal Account - Titipan hasil Klaim } \\
\text { Pendapatan klaim asuransi kredit }\end{array}$ & & $\mathrm{Xxx}$ & \\
& $\mathrm{xxx}$ \\
\hline
\end{tabular}

c. Jika ada angsuran dari nasabah setelah bank menerima ganti rugi, pembukuan dilakukan seperti Tabel 4.

Tabel 4. Jurnal umum penerimaan klaim

\begin{tabular}{|l|c|l|l|l|}
\hline No & Description & Ref & Debet & Credit \\
\hline & $\begin{array}{c}\text { Kas/Rekening Nasabah/Kas Kliring } \\
\text { Rekening Kredit atas nama debitur }\end{array}$ & & $\mathrm{Xxx}$ & \\
& $\mathrm{xxx}$ \\
\hline
\end{tabular}


Sedangkan formulir dan dokumen yang terkait dalam administrasi KUR Mikro di Bank BRI Pamekasan sebagai berikut: Formulir dan dokumen yang digunakan dalam prosedur administrasi KUR Mikro diantaranya seperti pada Tabel 5 .

Tabel 5. Formulir dan Dokumen yang digunakan untuk Administrasi KUR

\begin{tabular}{|c|c|}
\hline Formulir / Dokumen & Keterangan \\
\hline Form K5 KUR & $\begin{array}{l}\text { Formulir data nasabah yang mengajukan permohonan } \\
\text { pinjaman. }\end{array}$ \\
\hline Kwitansi Pinjaman & $\begin{array}{l}\text { Bukti realisasi pinjaman, yang menyatakan jumlah } \\
\text { pinjaman yang disetujui serta perhitungan pokok dan } \\
\text { bunga yang harus dibayar perbulannya. Kwitansi ini, } \\
\text { harus dibawa setiap kali melakukan pembayaran. }\end{array}$ \\
\hline $\begin{array}{l}\text { SPH (Surat Pengakuan } \\
\text { Hutang) }\end{array}$ & Surat perjanjian hutang antara debitur dengan bank \\
\hline Md. 35 & $\begin{array}{l}\text { Untuk mencatat permohonan KUPEDES (No. SKPP) } \\
\text { sampai dengan direalisir dan mengetahui lamanya } \\
\text { proses penyelesaian. }\end{array}$ \\
\hline $\begin{array}{l}\text { Md. } 35 \text { CA Bagian } \\
\text { Pertama }\end{array}$ & $\begin{array}{l}\text { Untuk mencatat NIP dan alat control susunan } \\
\text { penyimpanan berkas pinjaman berdasarkan } \\
\text { alphabetis nama debitur dan diurut nomor } \\
\text { pangkalnya. }\end{array}$ \\
\hline $\begin{array}{l}\text { Md. } 35 \text { CA Bagian } \\
\text { Kedua }\end{array}$ & Mencatat riwayat pinjaman nasabah \\
\hline Md. 35 DA & $\begin{array}{l}\text { Untuk mengontrol dokumen penting dan tanda terima } \\
\text { penyerahan dokumen kepada nasabah (Apabila } \\
\text { nasabah menyertakan agunan) }\end{array}$ \\
\hline
\end{tabular}

Kedua, Apakah dilakukan evalusi terhadap kemajuan usahanya bagi UMKM di kawasan Saè Salèra dan Saè Rassah Pamekasan yang menerima KUR dari Bank BRI? Berdasarkan wawancara peneliti dengan Bapak H. Ach. Suprapto, S.IP (Account Officer Komersial dan Program Bank BRI Cabang Pamekasan) dan 
Ibu Tuti Setiawati (Kaunit Bank BRI Trunojoyo Pamekasan) bahwa evaluasi terhadap UMKM di kawasan Saè Salèra dan Saè Rassah tentang kemajuan dan perkembangan usahanya dilakukan mulai dari pengajuan permohonan KUR Mikro dalam bentuk surfei kelayakan usaha, kemudian setelah mendapatkan dana KUR UMKM dimonitoring perkembangan usahanya setiap tiga bulan sampai selesai masa kredit oleh petugas lini atau lapangan Bank BRI cabang dan atau Unit. Fokus monitoring atau indikator kemajuan usaha UMKM berdasarkan pada jumlah omsetnya, modalnya, asetnya dan persediaan barang usahanya. Apabila ada UMKM yang mengalami penurunan indikator tersebut akan dilakukan pembinaan manajerial usahanya oleh petugas lini atau lapangan dari Bank BRI Pamekasan supaya tidak sampai pada ketidak mampuan menyelesaikan kewajibanya sebagi debitur KUR.

Hal tersebut sesuai dengan hak dan kewajiban keditur KUR, dimana hak dan kewajiban kreditur KUR pada Bank BRI di atur didalam from perjanjian KUR yang diberi judul Surat Pengakuan Hutang (SPH), SE. Nose : S.09DIR/ADK/03/2010 (SPH KUR MIKRO) dan PPK URB yang menjadi pedoman Bank BRI dalam memberikan layanan kredit bagi para nasabahnya, yaitu:

Hak pemberi kredit/kreditur KUR dalam pelaksanaan kredit KUR pada Bank BRI :

1. Menerima pembayaran dari pihak debitur dalam jangka waktu yang telah ditetapkan sesuai perjanjian termasuk mendapatkan bunga dengan ketentuan sebagaimana yang telah ditetapkan oleh pihak Bank;

2. Untuk kepentingan bank, dalam antisipasi terjadi wanprestasi bilamana tidak dilunasinya kredit oleh debitur KUR pihak Bank dapat menjaminkan pinjaman kredit ini kepada Perusahaan Penjamin;

3. Bank berhak baik dilakukan sendiri atau dilakukan oleh pihak lain yang ditunjuk Bank meminta keterangan dan melakukan pemeriksaan yang diperlukan kepada debitur KUR dan/atau perusahaan;

4. Bank berhak untuk memeriksa penggunaan pinjamin tersebut apakah telah sesuai dengan keterangan yang telah diterima pihak Bank, sebagaimana termuat dalam SPH KUR Mikro; 
5. Bilamana pinjaman digunakan untuk keperluan lain, maka bank berhak untuk seketika menagih pinjamannya berupa pokok, bunga, tambahan bunga, denda, biaya-biaya dan kewajiban lainnya yang mugkin timbul, dengan seketika dan sekaligus lunas.

Adapun yang menjadi kewajiban bagi kreditur/pihak Bank BRI, yaitu :

1. Memberikan kredit yang dipinjam oleh debitur sesuai dengan kesepakatan.

2. Memberikan bimbingan yaitu memberikan arahan kepada nasabah pada bidang-bidang yang kurang dimengerti sehingga usaha nasabah tersebut dapat dikembangkan dan tujuan akhir dari pemberian fasilitas KUR tersebut dapat dicapai.

3. Memberikan pembinaan, yang mencakup pembinaan secara administratif dan pembinaa secara langsung di lapangan. Pembinaan secara administratif pada dasarnya merupaka pembinaan belakang meja, yang didasarkan pada laporanlaporan atau surat menyurat secara aktif/pasif. Pembinaan dilapangan dilakukan dengan mengadakan kunjungan ketempat debitur secara langsung dengan maksud untuk mengamati manajemen perusahaan agar terpelihara dengan baik dan membantu mencari jalan keluar apabila debitur mengalami masalah.

4. Serta petunjuk kepada penerima kredit (nasabah) terutama dalam hal yang menyangkut manajemen dan pemasaran.

Sehingga, dengan adanya pengaturan yang jelas mengenai hak dan kewajiban debitur KUR dengan pihak Bank BRI tersebut maka kewajiban dan hak para pihak dalam perjanjian KUR diharapkan dapat berjalan seimbang.

Ketiga, Apakah kendala yang dihadapi oleh Bank BRI dalam menyalurkan KUR khususnya terhadap UMKM di kawasan Saè Salèra dan Saè Rassah Pamekasan? Berdasarkan wawancara peneliti dengan Bapak H. Ach. Suprapto, S.IP (Account Officer Komersial dan Program Bank BRI Cabang Pamekasan) dan Ibu Tuti Setiawati (Kaunit Bank BRI Trunojoyo Pamekasan) bahwa saat ini pada dasarnya tidak ada kendala yang dihadapi Bank BRI Pamekasan dalam penyaluran KUR Mikro. Hal ini karena para pengguna KUR Mikro sudah mengetahui tentang KUR Mikro.

jsh Jurnal Sosial Humaniora, Vol 5 No.1, Jun 
Kecuali pada awal-awal program ini memang Bank BRI mengalami kendala dalam penyaluranya antara lain, adanya animo masyarakat yang menganggap KUR ini sama dengan KUT sehingga diasumsikan bantuan modal dari pemerintah, padahal kenyataanya dana KUR ini berasal dari dana Bank BRI sendiri. Karena dana KUR dari dana Bank BRI sendiri yang berasal dari dana pihak ketiga sehingga bunga KUR dianggap terlalu tinggi oleh pelaku UMKM walaupun kenyataannya bungan KUR Mikro di Bank BRI telah sesuai ketentuan dari Kep. Men. Nomor: Kep-01/D.I.M.EKON/01/2010 yaitu tidak lebih dari 22 persen/tahun.

Kendala berikutnya minimalnya dana yang dimiliki Bank BRI dan kehatihatiannya Bank BRI dalam memberi persetujuan kredit KUR sehingga tarjet tidak terpenuhi, imbasnya saat ini penyalur KUR di perluas ke seluruh Bank Pembangunan Daerah (BPD).

Kehati-hatian pemberian kredit KUR ini karena banyaknya jenis usaha yang menjadi prasyarat pengajuan KUR Mikro tidak layak (tidak fiasible) apalagi bangible. Dan adanya usaha yang dilarang karena bertentangan dengan peraturan yang berlaku.

Jadi seiring waktu program KUR yang sudah berjalan hampir empat tahun ini Bank BRI sudah berpengalaman dalam mengatasi masalah tersebut diantaranya menyertakan anggunan sebagi ikatan moril antara kreditur denga debitur KUR Mikro walaupun tidak mengikat secara hukum. Selain itu semakin bertambahnya dana yang dimiliki Bank BRI dari pihak ketiga juga memperbanyak cakupan penyaluran KUR Mikro ini. Dan dalam rangka menjadikan usaha UMKM menajadi feasible Bank BRI melakukan pembinaan kepada UMKM yang berminat menjadi debitur sehingga berpeluang untuk mendapatkan bantuan modal usaha berupa KUR Mikro ini.

Dalam rangka memperbanyak cakupan debitur KUR Mikro yang nantinya diharapkan akan meningkatkan taraf hidup masyarakat dan perekonomian rakyat, maka alangkah baiknya jika Bank BRI melakukan usaha ;

1. Menambah jumlah Bank BRI Unit atau tempat-tempat pelayanan Bank

Pembantu yang terlibat dalam program KUR karena dengan jumlah bank yang 
melibatkan dalam penyaluran KUR sekarang ini, sulit diharapkan program KUR dapat diperluas dalam waktu singkat.

2. Mencari alternatif untuk menekan biaya transaksi baik melalui peningkatan efisien bank penyalur, maupun cara-cara lain yang layak dan tidak bertentangan dengan peraturan perundang-undangan.

3. Dengan meningkatkan kesiapan UMKM untuk memenuhi persyaratan teknis perbankan melalui berbagai cara baik melalui pembinaan mandiri maupun bekerjasama dengan pemerintah daerah.

4. Peningkatan jumlah dan kualitas petugas pendamping kredit dalam membantu UMKM dalam mengakses kredit.

5. Bekerja sama dengan pemerintah daerah dalam rangka peningkatan peran serta aparat pemerintah dalam menyiapkan calon debitur.

6. Mengawasi adanya pengalihan kredit Bank penyalur KUR untuk kelompok berpenghasilan rendah (yang juga sering dinyatakan sebagai UMKM) melalui berbagai perusahaan/lembaga keuangan formal seperti Leasing menjadi penyaluran langsung pada UMKM. Hal ini dimungkinkan sebab selama ini penyaluran secara tidak langsung tersebut digunakan untuk mengatasi masalah ketidakadaan agunan dari UMKM sehingga UMKM dianggap tidak layak untuk meminjam langsung ke Bank. Pimjaman UMKM atau kelopok masyarakat berpenghasilan rendah dalam bentuk kredit barang (terutama barang konsumtif) seperti kredit pembelian sepeda motor, barang elektronik dan alat-alat rumah tangga bisa di berikan karena barang tersebut bisa langsung dijadikan agunan.

Keempat, Apakah harapan Bank BRI sebagai Perbankan milik Pemerintah dan penyalur KUR terhadap pengembangan UMKM khususnya di kawasan Saè Salèra dan Saè Rassah Pamekasan? Berdasarkan wawancara peneliti dengan Bapak H. Ach. Suprapto, S.IP (Account Officer Komersial dan Program Bank BRI Cabang Pamekasan) dan Ibu Tuti Setiawati (Kaunit Bank BRI Trunojoyo Pamekasan) bahwa harapan secara khusus Bank BRI terhadap UMKM di kawasan Saè Salèra dan Saè Rassah tidak ada. Karena pada dasarnya kepedulian Bank BRI kepada UMKM secara umum sudah tertuang didalam misi Bank BRI 
yaitu "Bank BRI melakukan kegiatan perbankan yang terbaik dengan memprioritaskan pelayanan kepada Usaha Mikro, Kecil, dan Menengah (UMKM) untuk menunjang perekonomian masyarakat."

Dalam rangka merealisasikan misi diatas, karena program KUR ini merupakan program pemerintah dan Bank BRI merupakan lembaga Perbankan milik pemerintah maka seharusnya Bank BRI harus melakukan usaha-usaha pengembangan UMKM dengan strategi konkrit, antara lain:

Satu: Bank BRI secara sendiri atau berkelompok dapat membuat dan melaksanakan suatu sistem perkreditan yang khas, sehingga mempunyai nilai tambah bagi sektor UMKM, serta untuk sektor perbankan sendiri. Misalnya, melaksanakan program kredit yang bersifat individu, dapat dilakukan melalui strategi pendampingan secara langsung terhadap suatu UMKM sebagai mitra kerja. Dalam hal ini Bank BRI dapat memberikan pelatihan teknis produksi, pembenahan manajemen usaha dan akuntansi, strategi menembus dan memperluas pasar, serta meningkatkan kapabilitas manajerial para pelaku UMKM dibidang produksi, dan pengawasan penggunaan dana kredit. Selain itu perbankan dapat menjadi jembatan untuk memperlancar proses produksi, mulai dari penyiapan bahan bahu sampai penjualan hasil produksi.

Hal ini hanya dapat berjalan, misalnya jika Bank BRI membentuk unit bisnis strategis (SBU) sehingga Bank BRI dapat melancarkan transaksi UMKM mitra binaan dengan para pemasok dan meningkatkan akses ke pasar output. SBU tersebut perlu menyusun pula direktori produk mitra binaan sekaligus membuat daftar bahan baku atau penolong yang dibutuhkan, dimana daftar tersebut dapat disampaikan dalam jaringan internet sehingga mudah diakses.

Tentu saja hal ini tidak mudah dilaksanakan, karena akan berhadapan dengan beberapa kendala nyata, diantaranya biaya SDM pendamping serta biayabiaya lainnya yang harus dikeluarkan. Namun demikian, hal ini sebenarnya dapat diatasi dengan merekrut SDM dengan pola kontrak misalnya para sarjana-sarjana yang baru lulus tapi cerdas, dan beretika atau dari orang-orang profesional yang telah diketahui trade recordnya. Hal ini berimplikasi positif terhadap citra 
perbankan tersebut, karena sejalan dengan saran pentingnya perbankan daerah berusaha merekrut tenaga perbankan yang berasal dari daerah operasi mereka.

Dua: Perlu pula kiranya Bank BRI menerapkan sistem atau program kredit kepada kelompok UMKM yang baru tumbuh namun potensial, dan terutama kepada kelompok-kelompok usaha yang sudah mapan diberbagai bidang, seperti usaha wara laba, makanan khas daerah dan usaha kreatif lainnya. Sistem serupa ini mempunyai banyak keuntungan, seperti dapat mengeliminasi peluang penyalahgunaan dana kredit sehingga dapat mengurangi kredit bermasalah, kemudian dapat meningkatkan efisiensi usaha dalam hal pengadaan bahan baku, produksi dan pemasaran. Jika mekanisme produksi dan pemasaran berjalan lancar maka pengembalian kredit akan lancar pula.

Namun demikian sistem ini berhadapan juga dengan beberapa kendala, diantaranya mengenai pelunasan kredit kelompok sulit diramalkan karena keputusan dilakukan atas persetujuan anggota kelompok yang terkadang sulit menemukan keputusan. Selain itu kendala organisasi, akibat pimpinan kelompok terkadang bersifat mendua, yakni terkadang mewakili kepentingan usahanya atau kepentingan kelompoknya. Apalagi adanya kendala adminstrasi akibat kesalahan suatu anggota kelompok yang akhirnya menyebabkan Perbankan menjadi konservatif terhadap usaha kelompok secara keseluruhan.

Tiga: Bank BRI perlu membentuk jaringan kerja untuk meningkatkan jangkauan sektor perbankan ke sektor UMKM, baik secara individu maupun secara berkelompok, yang bersifat “mutual relationship". Dalam hal ini, diantaranya dengan cara menjalin kerjasama antar Bank BRI sendiri, yakni antara Bank BRI yang jaringan kantornya cukup luas dengan Bank BRI yang terbatas kantornya, atau bekerjasama dengan BPR-BPR yang umumnya beroperasi dekat dengan wilayah kerja UMKM masing-masing, serta melakukan kerjasama dengan lembaga-lembaga keuangan masyarakat lainnya di desa-desa atau perkotaan. Dalam hal ini kegiatan kerjasama tersebut bukan hanya berupa kegiatan distribusi dana saja, tapi berbagai kegiatan-kegiatan potensial lainnya yang dianggap dapat memberi keuntungan bersama.

jsh Jurnal Sosial Humaniora, Vol 5 No.1, Juni 


\section{Penutup}

Pada bab ini berisi kesimpulan dari pembahsan bab-bab sebelumnya, yang merupakan jawaban atas rumusan masalah penelitian ini. Kemudian akan disampaikan rekomendasi bagi pihak-pihak yang terkait.

1. Terkait cakupan KUR Mikro dari Bank BRI cabang Pamekasan di kawasan Saè Salèra dan Saè Rassah Pamekasan. Seluruh UMKM yang berada di kawasan Saè Salèra dan Saè Rassah Pamekasan telah menerima KUR baik Mikro maupun Ritel sejak tahun 2008 sampai sekarang. Ini menunjukan bahwa UMKM di kawasan Saè Salèra dan Saè Rassah Pamekasan mengetahui adanya program pemerintah tentang kredit bantuan modal usaha berupa KUR melalui Bank BRI, mengetahui prosedur pengajuannya dan mengetahui hak dan tanggung jawabnya sebagai debitur KUR Bank BRI.

2. Terkait evaluasi perkembangan UMKM yang mendapatkan KUR. Bank BRI Pamekasan selaku penyalur KUR Mikro langsung kepada UMKM sesuai dengan hak dan kewajibanya sebagai kreditur KUR telah melakukan hak dan kewajibanya dalam hal evaluasi perkembangan UMKM yang menerima KUR dari Bank BRI. Hak dan kewajiban tersebut tertuang dalam from perjanjian KUR yang diberi judul Surat Pengakuan Hutang (SPH), SE .Nose : S.09DIR/ADK/03/2010 (SPH KUR MIKRO) dan PPK URB yang menjadi pedoman Bank BRI dalam memberikan layanan kredit bagi para nasabahnya. Evaluasi atau monitoring ini dilakukan oleh petugas lini atau lapangan dari kantor Cabang Bank BRI Pamekasan dan atau Unit Trunojoyo dengan interval setiap tiga bulan sampai masa kredit selesai. Indikator perkembangan usaha UMKM yang di monitoring adalah omset, asset, modal dan persediaan barang yang di miliki UMKM dalam masa kredit.

3. Terkait kendala Bank BRI Cabang Pamekasan dalam penyaluran KUR Mikro. Pada dasarnya saat ini tidak ada kendala yang berarti dalam penyaluran KUR. Akan tetapi pada awal-awal program ini Bank BRI juga mengalami kendala penyaluran diantaranya: Adanya animo masyarakat bahwa KUR ini merupakan bantuan modal usaha dari pemerintah padahal dana KUR murni dari dana Bank; Terbatasnya persediaan dana yang dimiliki olah Bank BRI sehingga 
tarjet peyaluran tidak terpenuhi akibat kehati-hatian Bank BRI dalam menyetujui permohonan KUR dari UMKM; Dan banyaknya usaha yang tidak layak (fiasible) dan usaha yang dilarang (karena bertentangan dengan aturan dan hukum) sebagai prasyarat pengajuan permohonan KUR.

4. Terkait harapan Bank BRI Cabang Pamekasan terhadap UMKM di kawasan Saè Salèra dan Saè Rassah Pamekasan khususnya. Harapan Bank BRI Pamekasan terhadap UMKM di kawasan Saè Salèra dan Saè Rassah Pamekasan sejalan dengan misi Bank BRI yaitu "Bank BRI melakukan kegiatan perbankan yang terbaik dengan memprioritaskan pelayanan kepada Usaha Mikro, Kecil, dan Menengah (UMKM) untuk menunjang perekonomian masyarakat."

Sesuai dengan hasil pembahasan dan kesimpulan diatas, maka saran yang dapat dikemukakan adalah

1. Untuk Bank BRI Cabang Pamekasan dan Unit-Unitnya terus meningkatkan cakupan penyaluran KUR Mikro dengan berorientasi pada kelayakan usaha (feasible) dan bukan pada bankable dengan menekan serendah mungkin tingkat bunganya dan semudah mungkin prosedurnya serta melakukan monitoring dan pelatihan kepada UMKM secara periodik, sehingga semua UMKM khususnya Usaha Mikro bisa mendapatkan fasilitas program KUR dan menjadikan usahanya lebih feasible dan bankable.

2. Untuk UMKM dalam rangka menghadapi era globalisasi dan untuk meningkat perekonomian rakyat hendaknya hendaknya segera meningkatkan usahanya baik manajerial maupun proses produksinya yang salah satunya melalui penambahan modal usaha melalui KUR sehingga menjadi usaha yang feasible dan bankable.

3. Untuk Pemkab Pamekasan melalui Dinas Koperasi dan UKM hendaknya lebih ditingkatkan perannya dalam monitoring dan pembinaan secara berkala untuk menjadikan UMKM menjadi usaha yang feasible dan bankable, sehingga akan meningkatkan perekonomian dan kesejahteraan rakyat. Dan melalui Dinas Perindustrian dan Perdagangan hendaknya mempermudah pemberian ijin usaha 
kepada calon pelaku UMKM sehingga akan meningkatkan kemandirian dan perekonomian rakyat melalui usaha riil.

\section{Daftar Pustaka}

Arthesa, Ade., dan Handiman, Edia. , 2006. Bank dan Lembaga Keuangan Bukan Bank. Jakarta: Indeks

Furchan, Arif. , 1992 Metode Penelitian Kualitatif. Surabaya: Usaha Nasioanal

Hasibuan, Malayu., 2002. Dasar-Dasar Peerbankan. Jakarta: Bumi Aksara

Ife, Jim., 1995. Community Development: Creating Community Alternatives, Vision, Analysis and Practice. Australia: Longman

Kartono, Kartini., 1996. Pengantar Metodoloi Riset Sosial. Bandung: Mandar Maju

Kep. Men. Nomor: Kep-01/D.I.M.EKON/01/2010., Tentang: Operasional dan Prosedur Pelaksanaan Kredit Usaha Rakyat.

Kusmulyono, B.S., 2009. Menciptakan Rakyat Berusaha. Bogor: IPB Press

Moleong J, Lexy., 1990. Metodologi Penelitian Kualitatif. Bandung: Remaja Rosdakarya.

Muhajir, Noeng., 1996. Metodologi Penelitian Kualitatif. Yogyakarta : Rekesarasin

Nasution, S. , 1992, Metode Penelitian Naturalistik-Kualititif. Bandung: Tarsito

Nawawi, Hadari. ,1994, Penelitian Terapan. Yogyakarta: UGM University Press

Nota Facsimile No: B-113-MKR/PKM/07/2010., Tentang: Persyaratan KUR Mikro.

Nota Facsimili No B 146-MKR/KPM/10/2010 dan Surat Direktur UMKM No. B. 487-DIR/PPG/09/2010, Tanggal 21 September 2010., Tentang: Peningkatan Plafon KUR Mikro dari $5 \mathrm{jt}-20 \mathrm{jt}$.

Parson, et.al.,1994. The Integration of Social Work Practice, California: Brooks/Cole

Peraturan Menteri Keuangan Nomor: 189/PMK.05/2010., Tentang: Perubahan Ketiga Atas Peraturan Menteri Keuangan Nomor: 135/PMK.05/2008 tentang Fasilitas Penjaminan Kredit Usaha Rakyat.

Rappaport, J., 1984. Studies of Empowerment:Introduction to The Issue, Prevention In Human Issue. USA 
Rivai, Veithzal., dan Vethzal, Andria Permata., 2007. Credit Management Handbook. Jakarta: PT. Raja Grafindo Persada

Sadik A, Sulaiman., 2010. Jatidiri dan Budaya Madura. Surabaya: CV Karunia

Suharto, Edi., 1997. Pembangunan, Kebijakan Sosial dan Pekerjaan Sosial: Spektrum Pemikiran. Bandung: Lembaga Studi Pembangunan STKS

(LSP-STKS),

Suharto, Edi., 2006.Membangun Masyarakat Memberdayakan Rakyat: Kajian

Strategis Pembangunan Kesejahteraan Soaial \& Pekerjaan Sosial. Edisi

Kedua. Bandung: Rafika Aditama

Surat Edaran BRI Nose: S.09-DIR/ART/03/2010., Tentang Persyaratan Debitur KUR Mikro.

Surakmad, Winarno., 1980. Pengantar Penelitian Ilmiah dasar Metoda Tehnik. Jakarta: Tarsito

Surejo, Salim., , 2005. Pengembangan Masyarakat Pesisir. dalam Moh Ali Aziz,

ed. al., Dakwah Pemberdayaan Masyarakat: Paradigma Aksi Metodologi.

Yogyakarta: LkiS

Suyanto, Bagong dan Sutinah. ad., , 2006. Metode Peneltian Sosial: Berbagai

Alternatif Pendekatan. Edisi Pertama, Cetakan ke-2. Jakarta: Kencana

Suyatno, Thomas., 1990. Lalu lintas Pembayaran Dalam dan Luar Negeri. Jakarta: STIE Perbanan 
Swift, C dan G. Levin., 1987. Empowerment: An Emerging Mental Health Technology. Journal of Primary Prevebtin, USA

UU RI. No: 20 Tahun 2008., Tentang: Usaha Miko, Kecil dan Menengah.

jsh Jurnal Sosial Humaniora, Vol 5 No.1, Juni 2012 